\title{
CHANGING APPROACHES TO THE BISHOPSGATE QUESTIONS
}

\author{
WILL ADAM \\ Priest-in-Charge of Girton and \\ Ely Diocesan Ecumenical Officer
}

A glance at the Case Notes section of the Ecclesiastical Lar Journal over the last few years points the reader to a flurry of activity in alteration of listed church buildings. This is spurred on by (among other things) changing views and practice of liturgy, access for the disabled, repair of damaged buildings. replacement of worn fabric, making a building multi-purpose, comfort and audibility in worship, the incorporation of new technology, providing space for hospitality, accommodating children's work and commemorating the turn of the Millennium. Chancellors have had to strike a delicate balance between two opposing and contradictory points of view. On the one hand the view of some petitioners that "any alteration which is seen by the incumbent and congregation to be desirable in order to encourage and assist true worship should be permitted without outside restraint'. ${ }^{1}$ On the other hand the view of the heritage lobby' and others that "most of the churches in this land are national treasures of which the present incumbent and the present congregation are merely temporary occupiers and custodians with no right to make unnecessary or, as some would seem to argue, any alterations'. Whilst the ecclesiastical courts have at times placed a restraining hand on those seeking to alter church buildings, there is "no requirement in law either that a church should be maintained for all time in the state in which it happens to be at present, or that it should automatically be changed in accordance with the latest liturgical fashion'.+

In 1993 Chancellor Cameron (as she then was) granted a faculty for the radical re-ordering of St Helen's, Bishopsgate, in the City of London. ${ }^{5}$ The petitioners argued that the proposed alterations were necessary first to repair the structure and glazing damaged by two terrorist bomb blasts, and secondly for "pastoral and practical reasons" to improve access, comfort, visibility and audibility for the large congregation (often approaching six hundred). The chancellor reviewed the law relating to alterations to listed

' Re St Luke the Evangelist, Maidstone [1995] Fam 1 at 4. [1995] 1 All ER 321. [1994]

3 WLR 1165. (1994) 3 Ecc LJ 351. 13 CCCC No 19. Ct of Arches.

Although this is by no means all the amenity societies in all cases.

Re St Luke the Evangelist. Maidstone [1995] Fam I at 4. [1995] I All ER 321, [1994]

3 WLR 1165. (1994) 3 Ecc LJ 351. 13 CCCC No 19. Ct of Arches.

+ Re Holy Cross, Pershore (2001) 6 Ecc LJ 86, 19 CCCC No 35, Worcester Cons Ct (quotation from $\mathrm{p} 24$ of the original judgment)

"I am grateful to the Rt Worshipful Dr Sheila Cameron QC. formerly Chancellor of the Diocese of London. for lending me a copy of the unreported judgment in this case.

"Re St Helen's, Bishopsgate, 26 November 1993. 12 CCCC No 23, London Cons Ct. p 26. The case was noted in (1993) 3 Ecc LJ 256, but not on the three Bishopsgate questions. 
buildings, which at the time was based on the judgments of the Court of Arches in Re St Mary, Banbury ${ }^{7}$ and Re All Saints, Melbourn. ${ }^{*}$ She drew from these judgments and the views of the Secretary of State "that the burden of proof rests upon those who propose changes and seek to rebut the presumption' [against change of a listed building]. She went on to set herself three questions by which she would test the evidence in this case. These were:

1 Have the petitioners proved a necessity for some or all of the proposed works, either because they are necessary for the pastoral well-being of St Helen's, or for some other compelling reason?

2 Will some or all of the works adversely affect the character of the church as a building of special architectural and historic interest?

3 If the answer to (2) is yes, then is the necessity proved by the petitioners such that in the exercise of the Court's discretion a faculty should be granted for some or all of the works?

Subsequent judgments of the Court of Arches in Re St Luke the Evangelist. Maidstone" and Re St Mary the Virgin, Sherborne' ${ }^{12}$ affirmed Chancellor Cameron's approach and made the Bishopsgate questions a binding approach for chancellors. ${ }^{13}$ Chancellors, so bound, have been noted to be "loyally applying'/4 the Bishopsgate questions. They remain binding to this day although in recent years cracks have begun to appear in the consistency of the chancellors' approach to faculty petitions.

Over the years debates have been carried out through the pages of judgments about the definition of 'necessity', ${ }^{5}$ the role of pastoral considera-

Re St Mary, Banbury [1987] Fam 136, [1987] 1 All ER 247. [1987] 3 WLR 717. (1986) 1 Ecc LJ (2) 33, 7 CCCC No 11, Ct of Arches.

${ }^{8}$ Re All Saints, Melbourn [1992] 2 All ER 786, [1990] 1 WLR 833, 8 CCCC No 23. Ct of Arches.

* Department of the Environment Circular 8/87 on Historic Buildings and Conservation Areas, para 91. Cf Re St Helen's, Bishopsgate, p 11 (12 CCCC No 23).

10 Re St Helen's, Bishopsgate, p 15.

1 Re St Luke the Evangelist, Maidstone (cited in note 1 above).

12. Re St Mary the Virgin, Sherborne [1996] Fam 63. [1996] 3 All ER 769. [1996] 3 WLR 434, 15 CCCC No 10, sub nom Re Sherborne Abbey (1996) 4 Ecc LJ 685. Ct of Arches.

i3 At least in the Province of Canterbury. In Re Wadsle' Parish Church (2001) 6 Ecc LJ 172, 20 CCCC No 11, Sheffield Cons Ct, Chancellor McClean stated that he too considered himself bound by this approach.

it Re Wadsley Parish Church (cited in note 13 above), per McClean Ch, at para 20 of the full judgment. Cf e.g. Re St Michael the Archangel, Newqual (1995) 4 Ecc LJ 526. 14 CCCC No 15. Truro Cons Ct: Re St Chad, Romiley (Chadkirk) (1997) 4 Ecc LJ 769, 16 CCCC No 9, Chester Cons Ct; Re Emmanuel, Nort/mwod (1998) 5 Ecc LJ 213,17 CCCC No 18, London Cons Ct; and Re St Paul, Birkenshaw (2001)6 Ecc LJ 170, 20 CCCC No 10, Wakefield Cons Ct.

is E.g. Re St Gregory, Offchurch [2000]4 All ER 378. [2000] 1 WLR 2471. (2000) 6 Ecc LJ 82, 19 CCCC No 21, Coventry Cons Ct; Re St Mary the Virgin. Sherborne (cited in note 12 above). Quotations in this article from Hill. Ecclesiastical Law (2nd edn) (Oxford, 2001), pp 690-700. See also Re St John the Evangelist. Blackheath (1998) 5 Ecc LJ 217, 17 CCCC No 25, Southwark Cons Ct: Re All Saints. Hoingh on the Hill (2001) 6 Ecc LJ 414, 20 CCCC No 38. Lincoln Cons Ct: Re St Mary the Virgin, Essendon (2001) 6 Ecc LJ 415, 20 CCCC No 40. St Albans Cons Ct: Re Dorchester Abbey. (2002) 7 Ecc LJ 105, Oxford Cons Ct. 
tions in weighing evidence ${ }^{16}$ and the order in which the questions are asked.

The question of 'necessity' was discussed in the Court of Arches in Re St Mary the Virgin, Sherborne, ${ }^{17}$ where the Victorian Society appealed against the grant of a faculty to replace a nineteenth-century window with a more modern one. The judgment of the court ${ }^{18}$ stated inter alia:

The word 'necessity' has caused some trouble mainly because it has an objective and compulsive element. It is possible to argue that if a change is necessary it is a change which must be allowed no matter what objections there may be. However, we believe that in using this word in the context of there being three relevant [Bishopsgate] questions we are not indicating an absolute: we are indicating the approach which a responsible Church must have to listed buildings. The presumption is that there shall be no change."

In the Sherborne case the Court of Arches affirmed that 'the existing glazing cannot remain as it is and restoration is not a sensible or practicable option; necessity was thus proved. However, necessity is not confined to the unavoidability of repair work. It should be noted that the original Bishopsgate questions refer to proposed works having to be 'necessary for the pastoral well-being of St Helen's, or for some other compelling reason'. It has thus been possible to show that the presumption against change is rebuttable for 'pastoral reasons-giving chancellors a very wide discretion indeed. In Re St Helen's, Bishopsgate, that chancellor notes that in the Melbourn case "the Dean ... found that the petitioners had proved that the development proposed was necessary for the pastoral well-being of the church and this amounted to a "necessity".?0

Chancellor George, in Re St John the Evangelist, Blackheath,"1 tackled the definition of 'necessity' in the light of the above cases and guidelines from the world of secular planning law. ${ }^{22}$ He concluded that 'necessary' and 'necessity" are to be interpreted as 'something less than essential, but more than merely desirable or convenient; in other words something that is requisite or reasonably necessary'.23 This definition, though not binding on other chancellors, has been considered helpful by them and has appeared in the

16. E.g. Re Holy Cross, Pershore (cited in note 4 above); Re Wadsley Parish Church (cited in note 13 above); Re St Nicholas, Stillington (2000) 6 Ecc LJ 80, 19 CCCC No 13. York Cons $\mathrm{Ct}$.

Re St Mary the Virgin. Sherborne (cited in note 12 above).

is Sir John Owen, Dean. and Cameron and McClean Chs.

14 Hill. p 699.

so Re St Helens, Bishopsgate. p 12 (12 CCCC No 23).

$\therefore$ Re St John the Evangelist. Blackheath (cited in note 15 above).

$\because R e S t \mathrm{Johm}$ the Evangelist. Blackheath, at pp 28-31 of the original judgment (17 CCCC No 25). The relevant secular guidelines were contained in Department of the Environment Circular 8/87 and the Secretaries of State for the Environment and National Heritage publication PPG15. The chancellor also relied on the judgment of McCowan LJ in Sharkey $v$ Secretary of State for the Environment [1992] 2 PLR 11 at 19. CA.

3 Re St John the Evangelist, Blackheath, at p 31 . 
text of several subsequent judgments. ${ }^{2+}$ Applying this definition of "necessity', Chancellor George asked and answered the Bishopsgate questions in the order in which they originally appeared.

It has already been established ${ }^{25}$ that pastoral well-being can be a factor in proving that proposed work is necessary. However, it is clear that the process of applying for a faculty, especially where there are objectors from within the church and the case is heard in open court, can put a strain on pastoral relationships within the church. This was particularly noted in Re Holy. Cross, Pershore, ${ }^{26}$ where pastoral relations became so strained that the chancellor proposed that:

there is a fourth question that should always be asked. alongside the three posed in Bishopsgate-namely, what are likely to be the pastoral consequences, both short-term and looking further ahead, of making a proposed change??

This approach is problematic. First, it adds to the binding approach of the Court of Arches as laid down in the Maidstone judgment. Secondly, it is clear from a survey of cases following the Bishopsgate questions that such pastoral considerations are made by chancellors on the resolution of the questions as they stand. ${ }^{28}$ Chancellor McClean deals specifically with the possibility of a fourth Bishopsgate question in Re Wadsley Parish Church. ${ }^{29}$ in which he states:

I fear that I am not attracted by the notion of a 'fourth Bishopsgate question'. I believe that the Bishopsgate questions provide a framework which enables all relevant matters to be considered. What factors are relevant, and the weight each factor should be given, must depend on the particular constellation of facts: whether, for example, the parish is divided or is faced with opposition from without. I do not think it would be helful to develop a Bishopsgate catechism and so impose an unduly prescriptive framework on the balancing process chancellors must perform. ${ }^{30}$

The proposed fourth question has not been taken up by other chancellors.

The first major departure from the strict application of the Bishopsgate questions came in Re St Gregory; Offchurch. ${ }^{31}$ Towards the turn of the Millennium a number of petitions were presented for the introduction of

it E.g. Re Holy Cross, Pershore and Re St Mary the Virgin, Essendon (cited in notes 4, 15 above).

$2:$ I.e. in Re St Helen's, Bishopsgate and Re All Saints, Melhourn (cited in notes 6.8 above).

in Re Holy Cross, Pershore (cited in note 4 above).

17 Re Holy. Cross, Pershore (cited in note 4 above) at $\mathrm{p} 30$.

E.g. Re St Mary the Virgin, Essendon and Re St Nicholas. Stillington (cited in notes 15,16 above).

zy Re Wadsley Parish Church (cited in note 13 above).

3) Re Wadsley Parish Church at para 24.

"Re St Gregory; Offchurch (cited in note 15 above). 
stained glass windows to commemorate the event. The Sherborne case involved the proposed replacement of a decaying and damaged window-a course of action logically deemed 'necessary'. It is difficult in logic to show that the replacement of a sound window (whether clear or stained glass) with a commemorative window is absolutely 'necessary'. However, many such projects have been allowed by consistory courts. In Re St Gregory: Offchurch, Chancellor Gage concluded that such cases were different from the cases of 'radical changes in the church' ${ }^{32}$ such as the Maidstone, Banbury' and Melbourn cases upon which the Bishopsgate and other dicta were founded. The chancellor gave five guidelines, which he intended to follow in other Millennium window cases. These were as follows:

First, as the church is a listed building the strong presumption against change which would adversely affect its character as a building of architectural or historic interest will be adhered to whether or not this is a petition for a millennium window or some more radical alteration to the church.

Secondly, in cases involving a petition for a millennium window the first question that the court will ask itself is whether the new window adversely affects the character of the building as a building of special architectural or historic interest.

Thirdly, if the answer to the second question is no. then the court will still need to give effect to the presumption against change to a listed building but that presumption may be more readily rebutted.

Fourthly, if the answer is yes to the second question, the petitioners will need to show a necessity for change.

Fifthly, when the court is considering whether a necessity for change has been proved different considerations will apply where a window is involved than in cases involving re-ordering or more radical alterations. It is impossible to set out the circumstances in which the court will find a necessity proved. Each case will vary. Each should be dealt with on its own individual facts. ${ }^{3 .}$

This approach, when deconstructed, shows a departure from the strict use of the Bishopsgate questions, but only where Millennium windows are concerned. This approach reverses the order of the first two Bishopsgate questions: the question of whether the change will adversely affect a building is asked first, and the question of necessity second. This approach was followed by Deputy Chancellor Goodman in Re All Saints, Crondall, ${ }^{\text {it }}$ and by Chancellor Bursell in Re Dorchester Abbey, ${ }^{35}$ where the Chancellor managed to summarise the law on the subject without once mentioning the name 'Bishopsgate'.

Two other recent cases have seen the reversal of the order in which the first two Bishopsgate questions are asked. In Re St Peter's, Walworth, ${ }^{36}$ Chancellor George accepted:

$:$ Re St Gregory: Offchurch [2000] 4 All ER 382.

$\because$ Re St Gregory: Offchurch.

:- Re All Saints, Criondall (2002) 6 Ecc LJ 420. Guildford Cons Ct.

3 Re Dorchester Abher (2002) 7 Ecc LJ 105. Oxford Cons Ct.

:Re St Peter's, Waliorth (2002) 7 Ecc LJ 103, Southwark Cons Ct. 
the recent analysis of Mynors Ch in Re Parish of Stourbridge St Thomas ${ }^{37}$ that in all cases involving alterations to listed churches [author's italics] the questions to be asked are:

1. Do the proposed alterations adversely affect the character of the church as a building of special architectural or historic interest?

2. If they do, what is the necessity for carrying them out?

3. Does that necessity outweigh the adverse effect? ${ }^{3.8}$

Chancellor George agrees with Chancellor Mynors that this represents a departure from the order of the Bishopsgate questions - an order which the Court of Arches preferred in the Sherborne case. ${ }^{34}$ Yet Chancellor George (who in the Blackheath case ${ }^{+0}$ asked the questions in their original order ${ }^{+1}$ ) stated that 'I too consider that the questions are better asked and answered in the revised order, and that this can be done without in any way questioning that "the presumption is heavily against change". "2- Where Chancellor Gage reversed the order of the questions only in the case of Millennium windows, Chancellor George has extended this to 'all cases involving alterations to listed churches'.

It might seem that the order in which the questions are asked is immaterial. but this is not the case. If the first question is "has necessity been proved?" then, if this is answered in the negative, the questioning goes no further and the petition fails. As noted above, it is difficult to prove necessity, even pastoral necessity, in a case such as a Millennium window, so strict application of the Bishopsgate questions would lead to such projects being disallowed, laudable though they may be. If the first question to be asked is 'will the change adversely affect the character of the building?', then the second and third questions will be asked whatever the outcome. If the answer is 'no', the presumption against change remains but will be more easily rebutted. ${ }^{43}$ If the answer is 'yes', the petitioners still have to prove necessity and the chancellor uses his or her discretion in deciding whether to allow the works. This is a subtle but significant change in procedure. The Bishopsgate questions (in the order in which they appear) have been found wanting.

37 Re St Thomas, Stourbridge (4 December 2001), 20 CCCC No 39. Worcester Cons $\mathrm{Ct}$.

${ }_{38}$ Re St Peter's, Walworth at pp 27-28 of the original judgment, quoting from Re St Thomas, Stourbridge at pp 12-13 of the original judgment.

${ }_{3 \rightarrow}$ Re Si Peter's, Walworth, p 28.

4) Re St John the Evangelist, Blackheath (cited in note 15 above).

"Re St John the Evangelist. Blackheath, at pp $31 \mathrm{ff}$ of the original judgment (17 CCCC No 25).

+2 Re St Peter's, Walworth, p 28. The quotation is from Re St Mary the Virgin. Sherhorne [1996] Fam 63 at 77.

t3 In Re St Thomas, Stourbridge (cited in note 37 above). Chancellor Mynors stated that there is no presumption against change where the effect of the proposed works on the building is beneficial or neutral. Generally speaking, however. other chancellors have maintained a presumption against all change which is more easily rebuttable in cases where the effects are beneficial or neutral. 
However, in the Sherborne case the Court of Arches rejected argument that the second question (about adverse change to the character of the building) should be asked first. ${ }^{14}$ The judgment states that:

by the questions and their order we wish to stress the fact that with listed buildings the presumption is heavily against change. To change the order of the questions would, we believe, cause confusion and might seem to some to indicate a relaxation of the requirements before change will be authorised. No such relaxation is intended or desired by this court. ${ }^{45}$

The fears of the Court of Arches have proved to be misplaced in practice. Those chancellors who have changed the order of the questions have clearly set aside the approach laid down as binding by the higher court. However, they have not set aside the presumption against change. Nobody outside the most conservative parts of the heritage lobby would argue against Chancellor Mynors' claim that there is 'no requirement in law either that a church should be maintained for all time in the state in which it happens to be at present'. ${ }^{+6}$ At the same time nobody could claim that the difference of approach adopted by chancellors in recent years has opened the floodgates for unfettered and inappropriate re-ordering of listed buildings. Whilst the procedural approach of the courts has undoubtedly been altered, the protection afforded by the courts to the buildings in their care has not.

${ }^{4}$ Hill. p 699.

t5 Hill. p 699.

to Re Holy Cross, Pershore (cited in note 4 above). 